\title{
A Comparison of an Adaptive Neuro-Fuzzy and Frequency Ratio Model to Landslide-Susceptibility Mapping along Forest Road Networks
}

\author{
Nastaran Zare ${ }^{1, *}$, Seyed Ata Ollah Hosseini ${ }^{1}$, Mohammad Kazem Hafizi ${ }^{2}$, Akbar Najafi $^{3}$ (D), Baris Majnounian ${ }^{1}(\mathbb{D}$ \\ and Marten Geertsema ${ }^{4}$ \\ 1 Forest Engineering, Department of Forestry and Forest Economics, College of Agriculture \& Natural \\ Resources, University of Tehran, Daneshkadeh Ave., Karaj 77871-31587, Iran; at.hosseini@ut.ac.ir (S.A.O.H.); \\ bmajnoni@ut.ac.ir (B.M.) \\ 2 Department of Earth Physics, Institute of Geophysics, University of Tehran, North Kargar Street, \\ Tehran 14155-6466, Iran; hafizi@ut.ac.ir \\ 3 Department of Forest Science and Technology, Faculty of Natural Resources and Marine Sciences, \\ Tarbiat Modares University, Noor 46414-356, Iran; a.najafi@modares.ac.ir \\ 4 Research Geomorphologist, Ministry of Forests and Range, 1011 4th Avenue, Prince George, BC V2L 3H9, \\ Canada; Marten.Geertsema@gov.bc.ca \\ * Correspondence: n_zare1365@ut.ac.ir; Tel.: +98-9369132278
}

check for updates

Citation: Zare, N.; Hosseini, S.A.O.; Hafizi, M.K.; Najafi, A.; Majnounian, B.; Geertsema, M. A Comparison of an Adaptive Neuro-Fuzzy and Frequency Ratio Model to Landslide-Susceptibility Mapping along Forest Road Networks. Forests 2021, 12, 1087. https://doi.org/ 10.3390/f12081087

Academic Editor: Filippo Giadrossich

Received: 8 July 2021

Accepted: 10 August 2021

Published: 13 August 2021

Publisher's Note: MDPI stays neutral with regard to jurisdictional claims in published maps and institutional affiliations.

Copyright: (c) 2021 by the authors. Licensee MDPI, Basel, Switzerland. This article is an open access article distributed under the terms and conditions of the Creative Commons Attribution (CC BY) license (https:// creativecommons.org/licenses/by/ $4.0 /)$.

\begin{abstract}
In this research, we used the integration of frequency ratio and adaptive neuro-fuzzy modeling (ANFIS) to predict landslide susceptibility along forest road networks in the Hyrcanian Forest, northern Iran. We began our study by first mapping landslide locations during an extensive field survey. In addition, we then selected landslide-conditioning factors, such as slope, aspect, altitude, rainfall, geology, soil, road age, and slip position from the available Geographic Information System (GIS) data. Following this, we developed Adaptive Neuro-Fuzzy Inference System (ANFIS) models with two different membership functions (MFs) in order to generate landslide susceptibility maps. We applied a frequency ratio model to the landslide susceptibility mapping and compared the results with the probabilistic ANFIS model. Finally, we calculated map accuracy by evaluating receiver-operating characteristics (ROC). The validation results yielded $70.7 \%$ accuracy using the triangular MF model, 67.8\% accuracy using the Gaussian MF model, and 68.8\% accuracy using the frequency ratio model. Our results indicated that the ANFIS is an effective tool for regional landslide susceptibility assessment, and the maps produced in the study area can be used for natural hazard management in the landslide-prone area of the Hyrcanian region.
\end{abstract}

Keywords: ANFIS; frequency ratio; Hyrcanian forest; landslide

\section{Introduction}

Forest road networks provide essential infrastructure for the operation and transportation of products and the use of forest services, protection of forest resources, and achieving sustainable management goals [1-4]. However, forest roads can also increase landslide rates [5-11]. In the Hyrcanian forests in northern Iran, landslides are commonly associated with forest roads, and the trend is expected to continue [12,13]. Landslide susceptibility mapping and terrain stability mapping [14] should be used in the planning and construction of forest road networks to avoid landslide-induced damage to infrastructure and negative environmental impacts [5-11,15-17]. While landslides play an essential role as natural disturbance agents [18-20], roads can contribute to increased landslide rates due to cut and fill slope failures or drainage issues [11,21,22].

Brabb [23] defined landslide susceptibility (LS) as the probability of a landslide occurrence in a piece of land due to its local terrain attributes. The LS assessment has gained importance, as landslides cause intensive economic, human, and environmental losses 
globally each year [23]. Landslide susceptibility, hazard, and risk zoning should be integral components of land use planning. The result of landslides investigations may provide valuable data that help foresee such events, find measures to mitigate subsequent losses from future landslides [24] and build future roads in better locations.

The LS map indicates where future landslides are likely to happen, based on the recognition of areas of past landslides and areas where similar or identical physical characteristics exist $[25,26]$. In other words, LS maps are produced to help us recognize landslide-prone areas and adapt by creating landslide hazard mitigation procedures. Many approaches to LS evaluation have been proposed by increasing the use of GIS mapping and various models [27]. Many of these studies have recently applied various models, such as probabilistic, statistic, and data mining models. For the probabilistic model, the frequency ratio $[28,29]$, weight of evidence $[30,31]$, and evidential belief function $[32,33]$ have been applied. For the statistical model, logistic regression $[28,34]$ has been applied. For the data mining model, artificial neural network [35,36], neuro-fuzzy logic [35,37], support vector machines [38,39], and decision trees [39,40] have been used. Most LS maps are developed through soft computing techniques like fuzzy modeling and artificial neural networks. Combined neuro-fuzzy modeling has been applied to obtain LS maps [41-43]. Lee et al. [27] constructed LS maps for the Seorak mountain area, Korea, using an integration of frequency ratio and adaptive neuro-fuzzy inference system (ANFIS) in a geographical information system (GIS) environment. Oh and Pradhan [44] also produced LS maps using an ANFIS in a GIS environment. The validation results revealed that the LS maps constructed by the ANFIS predictive models using triangular, trapezoidal, generalized bell, and polynomial membership functions produced acceptable results (AUC $=84.4 \%$ ) for preliminary land-use planning. Similarly, Polykretis et al. [26] carried out an LS assessment of a Mediterranean hilly area through ANFIS modeling. In this case, six ANFIS models, each with a discrete membership function, were produced to obtain corresponding LS maps.

The 890,680 ha of the three northern provinces of Iran have forest management booklets and some 10,000 km of constructed forest roads [45]. The relationship between forest roads and geomorphic processes lies at the heart of several key issues concerning the effects of roads on the environment [7]. Roadside slope failure is a usual difficulty in the Caspian forest, as naturally formed slopes are disturbed by road construction projects. A literature review of LS modeling indicates that a few different methods have been used in the study area, such as Multivariate Regression [46], each having its advantages and disadvantages. ANFIS was used for the first time in our study area. This study follows the landslide modeling of various researches in other forests within Mazandaran Province [47-50]. The main differences between the various researches are related to landslide susceptibility models and factors affecting landslide occurrence according to the conditions of the study area.

In summary, the main aim of this study is to investigate the distribution status of the existing roads in the landslide susceptibility map obtained using ANFIS. The spatial distributions of landslide susceptibility levels are helpful for the logical dedication of resources to landslide prevention and mitigation, contributing to avoiding landslide hazards with lower costs. The outcomes of this study are valuable references, which can help forest managers be able to both ensure that future road network construction does not occur on environmentally sensitive areas and reduce the conservation costs of existing roads by identifying landslide-prone areas.

\section{Materials and Methods}

Our approach to conduct and improve LS mapping consists of four steps:

1. First, we characterize the study area;

2. Secondly, we present data production and landslide-triggering factors;

3. Thirdly, we describe our methods, of development and training of ANFIS algorithms; and application of ANFIS for LS mapping in the study area; 
4. Fourthly, we perform the validation of the LS maps, using the receiver operating characteristics-based area under curve method.

\subsection{Study Area}

We selected a landslide-prone area in Mazandaran Province, northern Iran (Figure 1) for LS mapping using an ANFIS based neuro-fuzzy model. The area is located between latitude $36^{\circ} 27^{\prime} 07^{\prime \prime}$ and $36^{\circ} 18^{\prime} 18^{\prime \prime} \mathrm{N}$ and longitude $53^{\circ} 01^{\prime} 11^{\prime \prime}$ and $53^{\circ} 10^{\prime} 58^{\prime \prime} \mathrm{E}$, covers an area of 11,700 ha, and has $240 \mathrm{~km}$ of forest roads. The lowest and highest elevations of the area are 180 and 1010 m.a.s.l., respectively. The slope percentage of the area ranges from $0 \%$ to as much as $70 \%$. Given the proximity to the Caspian Sea, the study area enjoys a humid and mild climate, with average annual precipitation between 590 to $810 \mathrm{~mm}_{\text {year }}{ }^{-1}$. The average summer and winter temperatures are 32.4 and $1.8^{\circ} \mathrm{C}$, respectively.

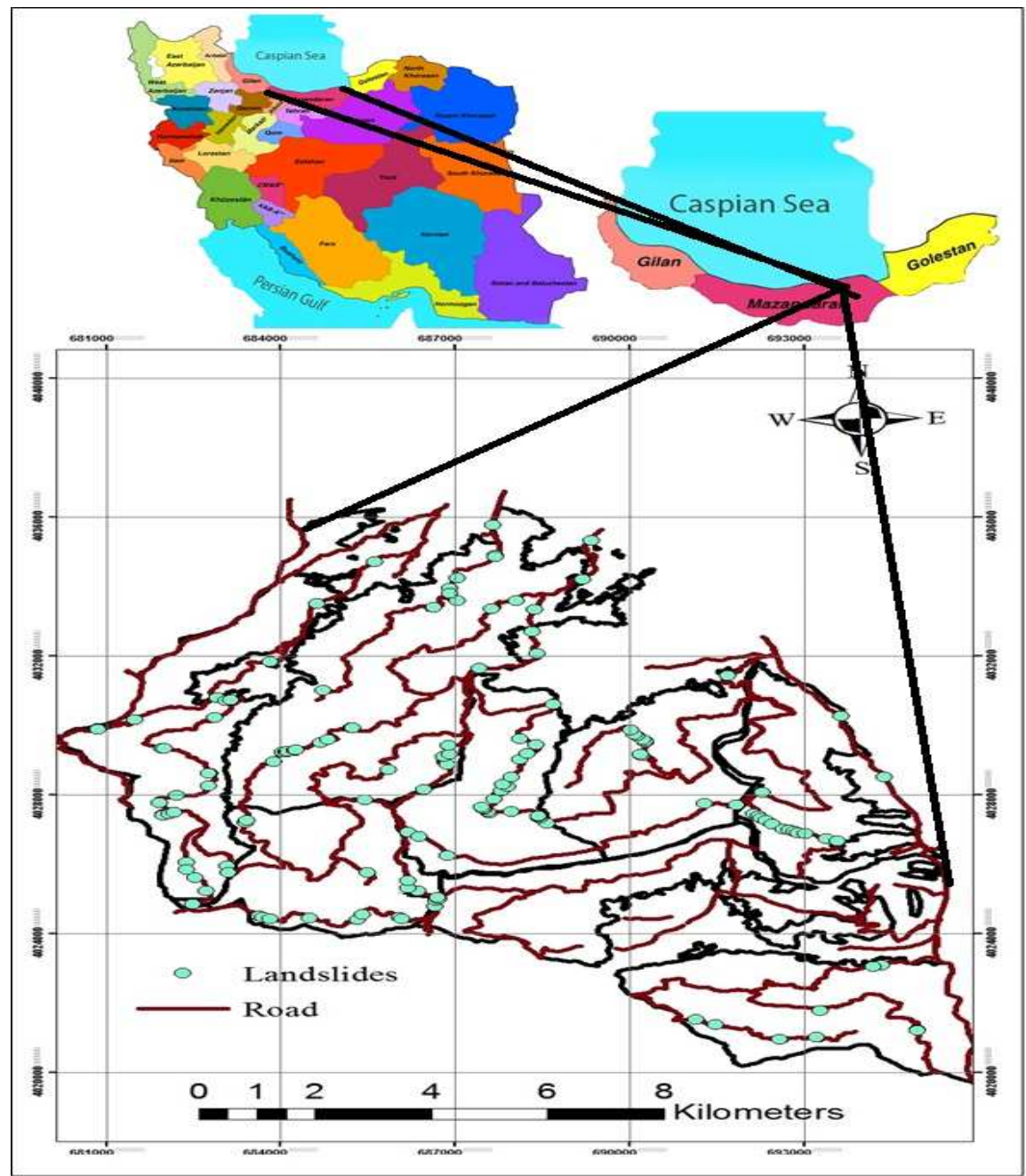

Figure 1. Location of the study area with landslide inventory map.

According to a geologic map of the area, prepared by the Geological Survey of Iran (GSI), the major portion of the study area is underlain by dolomitic limestone. The Alborz fault is the most important fault in the area and is an active reverse fault that follows the east-west orientation and dips toward the south.

\subsection{Data Collection}

We used field surveys along roads to identify and map landslides in our study area. We collected information about: (1) the characteristics of landslides; (2) geological con- 
ditions; (3) surface water or groundwater situation and their effects on instability; (4) instability observations such as creep, improper drainage, tension cracks; and (5) climatic conditions [51]. Our database for LS mapping includes the map of previously existing landslides and a series of causal or contributing factors. Our investigation occurred along with the road network and included shallow debris slides, flows, rockfalls and slides. Previous landslides occurred above roads on cut slopes and where there was soil below roads, either from drainage or fill slope failures (Figure 2).

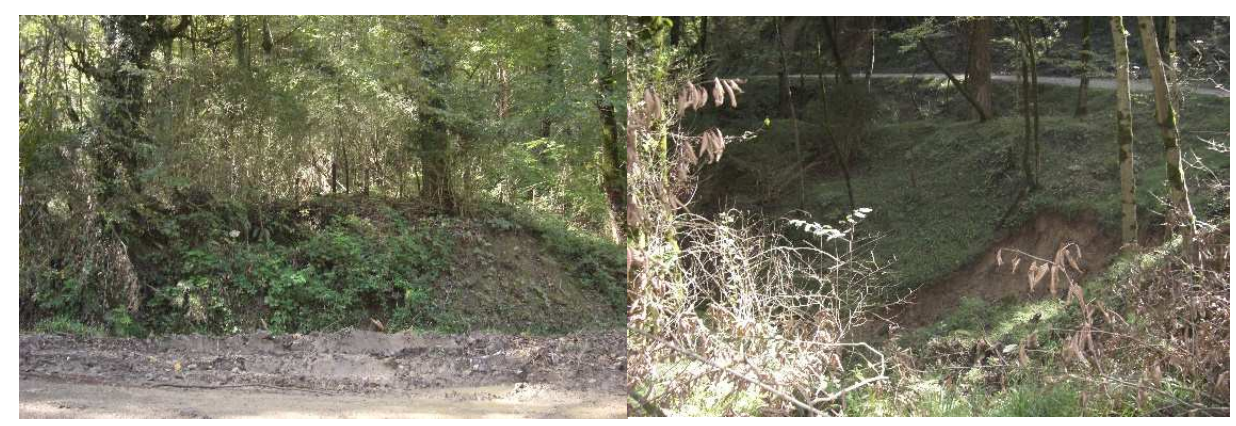

(a)

(b)

Figure 2. Landslides photos including: (a) cut slop; (b) fill slope.

\subsection{Spatial Database Construction}

\subsubsection{Preparing Landslides Inventory Map}

Since landslide occurrence in the past and present are important to future spatial prediction, a landslide inventory map is a prerequisite for such a LS study $[24,52,53]$. The landslide inventory map helps to be clear of the various factors that contribute to instability. A landslide inventory map was a prerequisite for obtaining a landslide zoning map for this research study area. We evaluated landslides along the forest road network managed by Mazandaran Wood and Paper Industries in order to carry out this investigation. We surveyed both the lower and upper edges of the roads and recorded the locations of landslides with a GPS. Due to relatively dense forest cover, no landslides were observed using aerial photos.

Furthermore, no previous reports of landslides were found. This is in line with the research of Brardinoni et al. [54] who found that up to $85 \%$ of field-identified landslides may not be visible on air photos. The location of the landslides was prepared as a point layer in the GIS environment and the area of each landslide was measured using field surveys. In this study, we used polygons to display 150 landslides. Mean polygon size is about $2000 \mathrm{~m}^{2}$. The landslide polygons form the basis of further LS zonation.

\subsubsection{Landslide Causal Factors}

In LS mapping, it is expected that future landslides will happen under the same situations that caused prior landslides [53]. The diagnosis and mapping of an appropriate set of instability factors related to slope failures require former information about the original causes of landslides [55]. Selecting causal factors for application in the analysis can be carried out through a relatively flexible approach, and thus, the covariates selected in different studies vary within a broad range [56]. They ought to be chosen based on location, the scale of the area, the characteristics of the study area and the type of slip. In addition, the determination of landslide causal factors was associated with data availability [57].

The selection of the factors affecting the slip is also based on previous studies for the study area [58-63]. In general, for any model to function in a particular region, its input factors are selected with access to some reliable information and access restrictions to some other information. According to the research method used in the review, the factors of slope, aspect, altitude, rainfall, geology, soil, road age, and slip position were used (Figure 3). All of these data are commonly used in LS mapping. The research carried out by Budimir et al. [64] clearly indicates that among the 37 parameters that are generally 
used in landslide vulnerability mapping, the attributes of slope, aspect, and geology are most frequently applied, particularly in studies of rainfall-induced landslides. The relation of the spatial data combination used in the prediction became a significant issue in LS mapping [65]. Since the raster dataset has enriched capacity for spatial analysis, all factor layers were converted into a raster template. Given the extent of the study area and the landslide distribution, grid cells with a spatial resolution of $20 \times 20 \mathrm{~m}[24,58,66]$ were chosen as the mapping unit, which was small enough to capture the spatial characteristics of LS and large enough to diminish computing complexity.

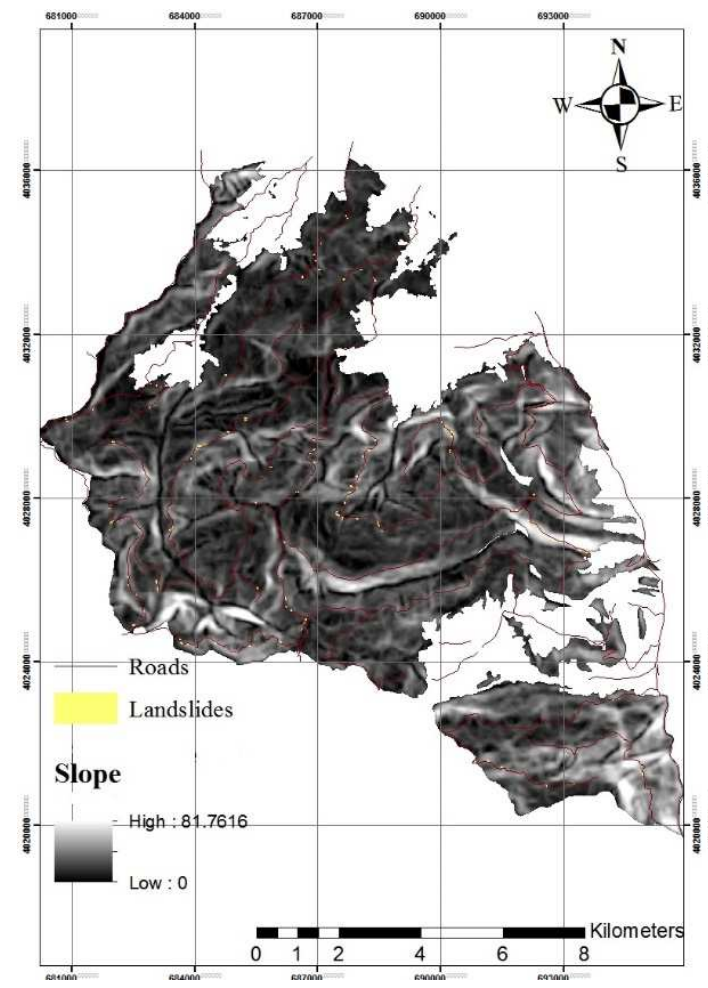

(a)

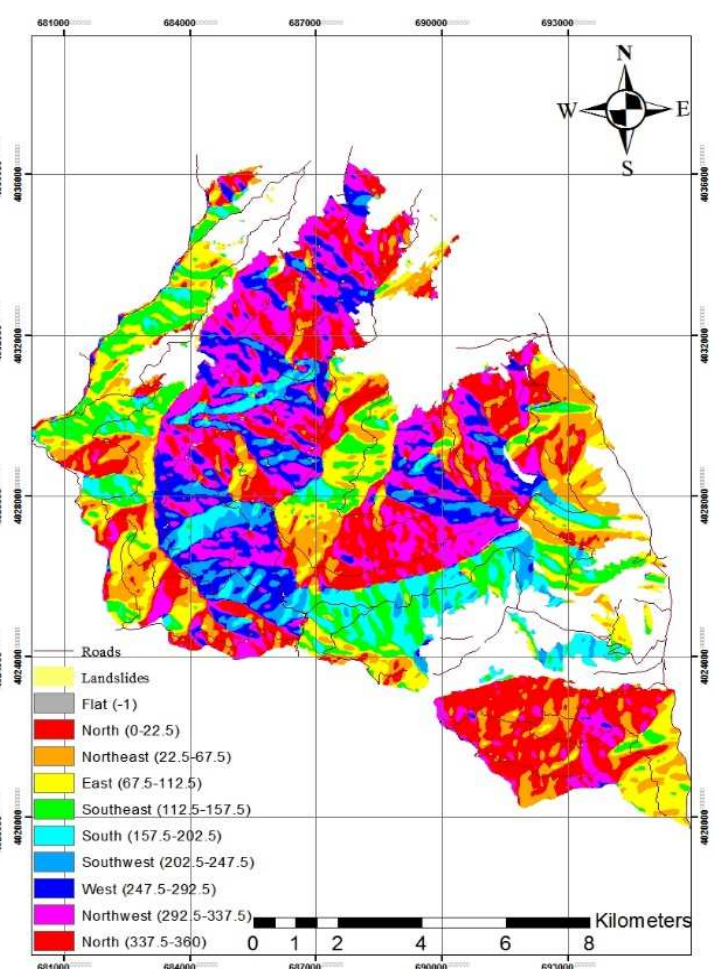

(b)

Figure 3. Cont. 


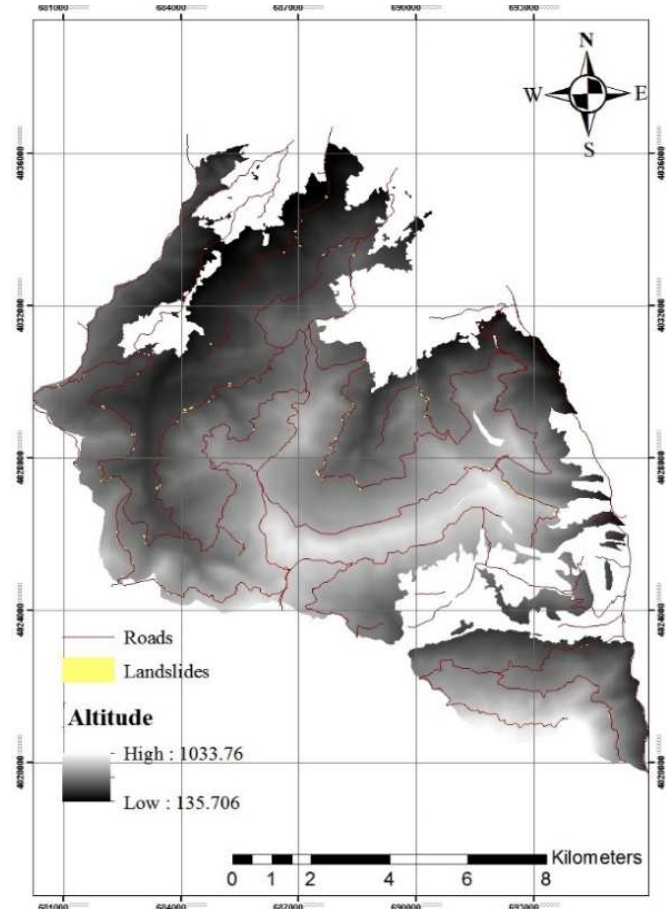

(c)

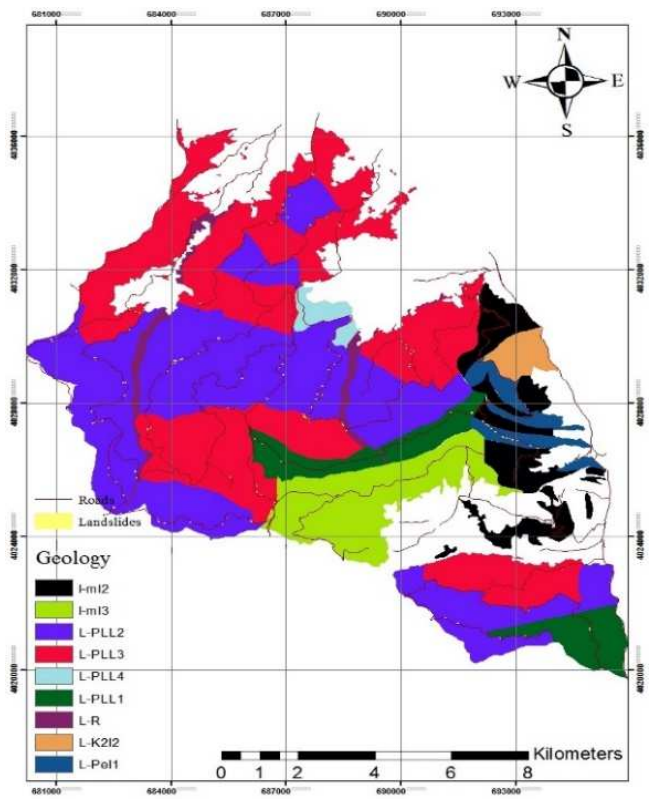

(e)

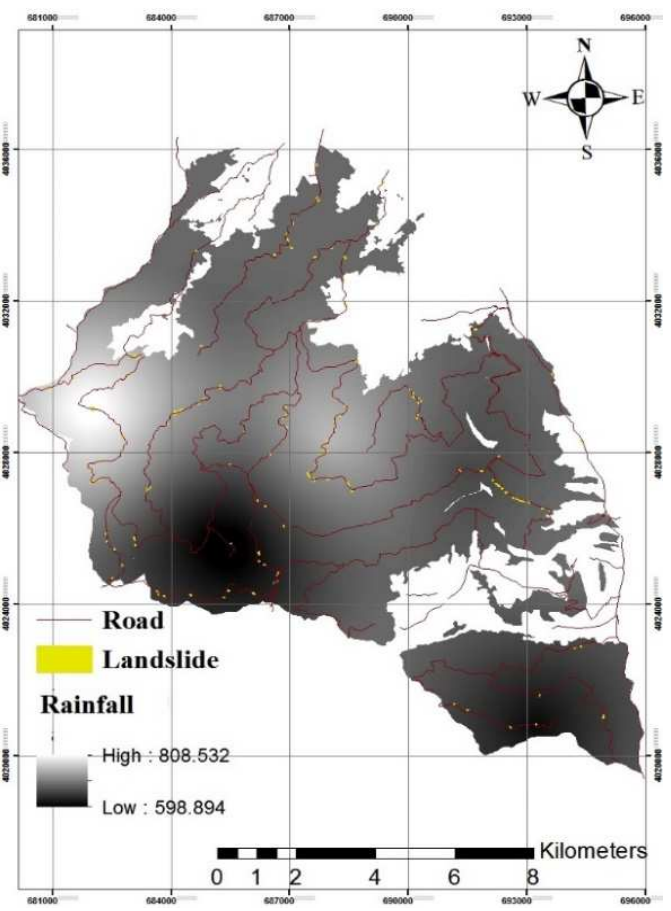

(d)

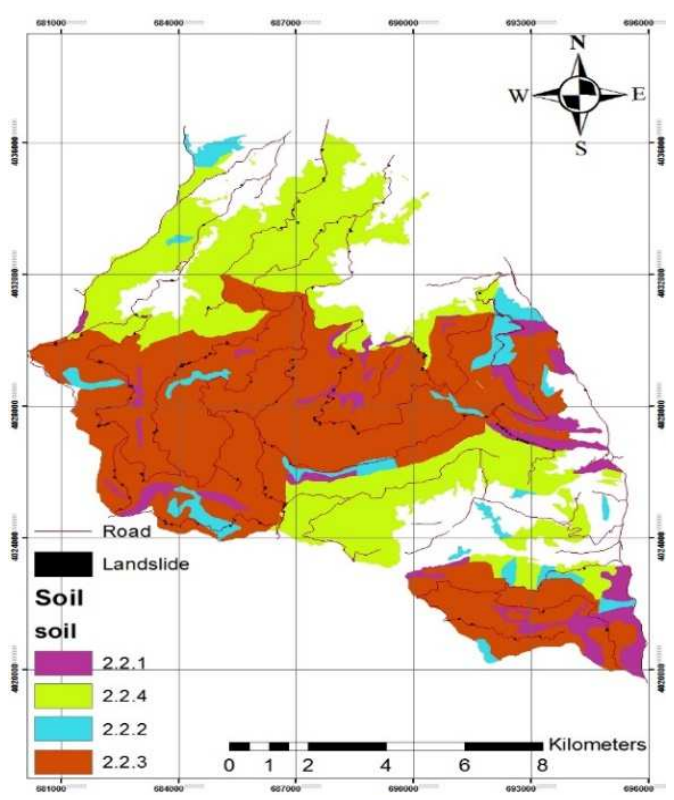

(f)

Figure 3. Cont. 


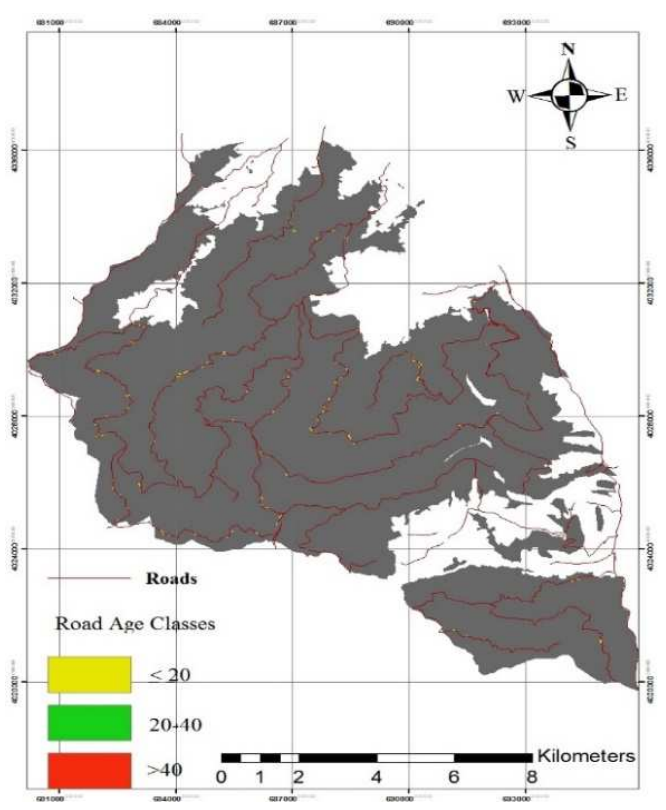

(g)

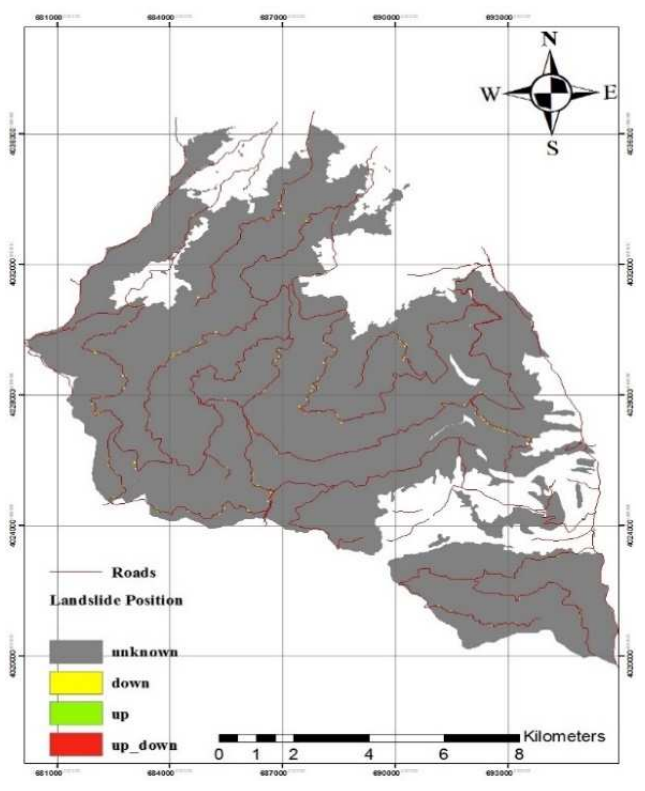

(h)

Figure 3. Maps of landslide-conditioning factors: (a) slope; (b) aspect; (c) altitude; (d) rainfall; (e) geology; (f) soil; (g) road age; (h) slip position. Description: Soil texture map (2.2.1: Loam, Clay-Loam, 2.2.2: Silt-Clay-Loam, Clay-Loam, 2.2.3: Loam, Clay-Loam, Clay, 2.2.4: Clay-Loam, Si-Clay). Geology map (L-PLL4: Lime Marine Rock, Sand Lime Rock, L-PLL3: Sand Lime Rock, Lime Silt Rock, Lime Marine Rock, Marine Rock, Conglomerate Rock, L-PLL2: Lime Marine Rock, Marine Rock, Sand Lime Rock, Lime Silt Rock, L-PLL1: Lime Marine Rock, Lime Rock, Marine Rock, Sand Lime Rock, Lime Silt Rock, L-R: River alluviums, 1-ml2: Sand Lime Rock, Conglomerate Rock, l-ml3: Lime Silt Rock, Marine Rock, L-K212: Sand Lime Rock, Lime Marine Rock, L-Pel1: Conglomerate Rock).

\subsection{Adaptive Neuro-Fuzzy Inference System}

\subsubsection{Application of Frequency Ratio for ANFIS}

In general, landslide prediction requires the assumptions that the occurrence of a landslide relates to its attributes and also that future landslides are likely to happen under the same conditions as previous landslides did [53]. The level of relationship between the landslide points and the factors affecting their occurrence must be determined in order to weigh each of the influential factors in landslides for ANFIS input. There are several methods to determine the correlation, among all models; the frequency ratio method has been used in this study. The frequency ratio approach was first used utilizing GIS in order to construct the landslide susceptibility map quantitatively [67]. The ratio is determined by the area where landslide occurrences are found in comparison to the total study area, and the ratio of landslide probability occurrences to the non-occurrences for a given attribute [68]. The frequency ratio for each factor's class or type was then calculated from its communication with landslide events. Larger ratios indicated a stronger correlation between landslide occurrences and relevant factor attributes [69,70]. As shown in (Equation (1)), the Landslide Susceptibility Index (LSI) is obtained from the summation of each factor's ratio value:

$$
\mathrm{LSI}=\sum \mathrm{FR}
$$

where FR is a rating of each factor's type or range, FR is expressed as follows (Equation (2)):

$$
F R=\frac{\frac{N_{\text {pix }}\left(S X_{i}\right)}{\sum_{i=1}^{m} S X_{i}}}{\frac{N_{\text {pix }}\left(X_{j}\right)}{\sum_{j=1}^{n} N_{\text {pix }}\left(X_{j}\right)}}
$$

In which (according to [71]): 
$\mathrm{N}_{\text {pix }}\left(\mathrm{SX}_{\mathrm{i}}\right)$ : number of pixels with landslides within class $\mathrm{i}$ of factor variable $\mathrm{X}$,

$\mathrm{N}_{\text {pix }}\left(X_{j}\right)$ : number of pixels within factor variable $X_{j}$,

$\mathrm{m}$ : number of classes in the parameter variable $X_{i}$,

$\mathrm{n}$ : number of factors in the study area.

The frequency ratio model can be developed by GIS with easy-to-understand results $[69,72,73]$.

Due to the different scales of input variables, and in order to increase the speed and accuracy of data processing, input data need to be normalized in the range of 0 and 1 before using them in the ANFIS model [59]. For this purpose, the frequency ratio of each landslide conditioning factors class was normalized using the normalization formula as follows (Equation (3)):

$$
X_{n}=\frac{X_{i}-X_{\min }}{X_{\max }-X_{\min }}
$$

\subsubsection{Preview of ANFIS}

ANFIS is a multilayer feed-forward network in which each node performs a particular function on incoming signals and has a set of parameters in relation to this node [74]. In order to calibrate a rule-based fuzzy inference system that simulates the human's brain information processing, fuzzy logic and ANNs are combined in ANFIS based on ANNs mathematical properties [75]. The ANFIS model is implemented as a first-order Takagi and Sugeno's type fuzzy inference system [76] that consists of two fuzzy if-then rules (Equations (4) and (5)):

Rule 1: If $\mathrm{x}$ is $\mathrm{A} 1$ and $\mathrm{y}$ is $\mathrm{B} 1$ then $\mathrm{f} 1=\mathrm{p} 1 \mathrm{x}+\mathrm{q} 1 \mathrm{y}+\mathrm{r} 1$

Rule 2: If $x$ is $A 2$ and $y$ is $B 2$ then $f 2=p 2 x+q 2 y+r 2$

where:

$\mathrm{x}, \mathrm{y}$ are inputs,

A, B corresponding term set,

output,

$\mathrm{p}, \mathrm{q}, \mathrm{r}$ constant.

An ANFIS model applies a learning algorithm to input datasets and compares the estimated outputs with their corresponding actual values, aiming to optimize the parameter values of the equivalent fuzzy inference system. The parameter optimization is done during the training session and the error between the target and the actual output is minimized. Further information on ANFIS can be found in Jang [74]. Different membership functions can be used to modify this method. We used two triangular and Gaussian functions in this study.

\subsubsection{Preparation of the Training and Testing Data Set}

In LS mapping with ANFIS, the landslide inventory map needs to be split into two subsets: training and test data $[44,58,77]$. The model training location should be determined prior to running the ANFIS model [42]. It is expected that the training data include all the data belonging to the problem domain [77]. The training data are applied to train the model and produce the weights of the network. On the other hand, the test data should be different from those used in the training stage [77]. Validation of model results could not be carried out without dividing the data sets [58]. No exact mathematical rule to determine the required minimum size of these subsets exists [42,44]. In this study, the inventory map was randomly divided into two datasets. Part 1 contains $70 \%$ of the data (105 numbers) used in the training phase of the two ANFIS models. Part 2 is a validation dataset with the remaining $30 \%$ of the data ( 45 numbers) for the validation of the models and to estimate their accuracy. 


\subsubsection{Validation of the Landslide Susceptibility Maps}

LS maps in a region need appropriate validation. In landslide modeling, validation of predictive landslides is an essential part of the evaluation procedure [24]. In terms of its precision in landslide prediction, the success of landslide susceptibility modeling can be obtained by comparing the model's results with actual data at known landslide locations. The receiver operating characteristic (ROC) curve is a helpful procedure for representing the quality of deterministic and probabilistic detection and predict systems. The area under the curve (AUC) is an excellent indicator to check the model's forecast efficiency and the largest AUC, varying from 0.5 to 1.0, is a perfect model.

\section{Results}

\subsection{The Application of Frequency Ratio}

Correlations between previously occurring landslide locations and their discrete factors were obtained through the frequency ratio (FR) method. In general, factor classes with a FR value of $>1$ will have higher probability of landslide occurrence [57]. Table 1 shows the FR value for each landslide causal factor. Weights obtained by frequency ratio between the position factor and landslides was 1.28 (Table 1). This showed that most of the landslides happened at the road's embankment (fill slope). One of the factors that can increase shear stress along a potential fracture surface is the increase in weight of, or loading on, the domain material. The embankment is a type of loading that leads to increased shear stress [51].

In our study, the results showed that as the road age increases, landslides decrease (Table 1). A few studies showed that landslides increased in old roads that are not under maintenance management [11], often because of improper drainage control. However, as old road surfaces revegetate, root strength and evapotranspiration play an important role in stabilizing slopes. The establishment of vegetation on cut and embankment slopes with reinforcement features and slope drainage can help to stabilize and increase soil shear resistance to failure. The latter seemed to play a role in this study [13].

The ratio weights obtained between the soil factor and the landslides showed that fine-textured soils (loam, clay loam, and clay) with good to poor water permeability had the highest number of landslides (Table 1), consistent with results of other studies [27,44,60].

Altitude is usually considered to be an important conditioning factor in territorial landslide susceptibility prediction, especially for areas where altitudes change dramatically [78]. Most of our landslides occurred between 600 and $900 \mathrm{~m}$ in the upper part of the watershed. In mountainous areas, factors, such as temperature, moisture, vegetation, biological activities and engineering constructions, tend to differ with elevation, which causes landslides to spread in a certain range of altitudes [61].

The calculated ratio weight between the slope factor and the landslides indicated that most landslides occurred at slopes of $50 \%$ to $60 \%$, consistent with the results of other studies $[26,27,44,57,62]$. Steeper slopes tend to be rock controlled and therefore more stable for soil landslides, and gentle slopes are also relatively stable because they have greater resisting forces than driving forces $[58,69,72]$. Thus, the most frequent landslides often occur on average slopes hosting soil cover.

The weights obtained from the linkage between precipitation and landslides by the frequency ratio showed that the landslide likelihood increases where precipitation is greater than $800 \mathrm{~mm}$ (Table 1). This result corresponds to the results of Jaafari et al. [62], Dehnavi et al. [79], Hong et al. [80], and Jaafari et al. [58]. A positive correlation between rainfall duration, intensity, pattern and sequence of precipitation, and landslide occurrence has been reported in various studies, although this varies between landslide types [81]. Severe rainfall increases pore water pressure [82] and reduces the shear strength of shallow soils relatively quickly. 
Table 1. Spatial relationship between landslide and landslide-conditioning factors.

\begin{tabular}{|c|c|c|c|c|c|c|}
\hline Factor & Class & Landslide & Landslide (\%) & Domain & Domain (\%) & Frequency Ratio \\
\hline \multirow{8}{*}{ Slope $(\%)$} & $0-10$ & 32 & 4.67 & 34,780 & 11.96 & 0.39 \\
\hline & $10-20$ & 194 & 28.32 & 123,512 & 42.46 & 0.67 \\
\hline & $20-30$ & 217 & 31.68 & 77,526 & 26.65 & 1.19 \\
\hline & $30-40$ & 129 & 18.83 & 35,372 & 12.16 & 1.55 \\
\hline & $40-50$ & 64 & 9.34 & 13,178 & 4.53 & 2.06 \\
\hline & $50-60$ & 48 & 7.01 & 4867 & 1.67 & 4.19 \\
\hline & $60-70$ & 1 & 0.15 & 1452 & 0.5 & 0.29 \\
\hline & $>70$ & 0 & 0 & 195 & 0.07 & 0 \\
\hline \multirow{8}{*}{ Aspect } & $\mathrm{N}$ & 172 & 25.15 & 65,080 & 22.37 & 1.12 \\
\hline & $\mathrm{NE}$ & 192 & 28.07 & 39,423 & 13.55 & 2.07 \\
\hline & $\mathrm{E}$ & 84 & 12.28 & 37,376 & 12.85 & 0.96 \\
\hline & SE & 50 & 7.31 & 30,595 & 10.52 & 0.7 \\
\hline & $\mathrm{S}$ & 22 & 3.22 & 21,996 & 7.56 & 0.43 \\
\hline & SW & 15 & 2.19 & 15,284 & 5.25 & 0.42 \\
\hline & W & 55 & 8.04 & 29,530 & 10.15 & 0.79 \\
\hline & NW & 94 & 13.74 & 51,613 & 17.74 & 0.77 \\
\hline \multirow{4}{*}{ Altitude (m) } & $<300$ & 54 & 7.91 & 28,058 & 9.67 & 0.82 \\
\hline & $300-600$ & 387 & 56.66 & 176,522 & 60.87 & 0.93 \\
\hline & $600-900$ & 242 & 35.43 & 84,007 & 28.97 & 1.22 \\
\hline & $>900$ & 0 & 0 & 1435 & 0.49 & 0 \\
\hline \multirow{3}{*}{ Rainfall (mm) } & $<650$ & 87 & 12.70 & 37,702 & 12.93 & 0.31 \\
\hline & $650-750$ & 535 & 78.10 & 237,134 & 81.32 & 0 \\
\hline & $>750$ & 63 & 9.19 & 16,748 & 5.74 & 1 \\
\hline \multirow{3}{*}{$\begin{array}{l}\text { Landslide } \\
\text { position }\end{array}$} & Fill slope & 404 & 66.12 & 30 & 61.22 & 1.28 \\
\hline & Cut slope & 177 & 28.96 & 17 & 34.69 & 0.83 \\
\hline & Both & 30 & 4.9 & 2 & 4.08 & 1.20 \\
\hline \multirow{3}{*}{ Road age } & $<20$ & 141 & 23.19 & 10 & 20.83 & 1.11 \\
\hline & $20-40$ & 453 & 74.5 & 34 & 70.83 & 1.05 \\
\hline & $>40$ & 14 & 2.3 & 4 & 8.33 & 0.28 \\
\hline \multirow{4}{*}{ Soil properties } & 2.2 .1 & 73 & 10.76 & 21,430 & 7.4 & 1.45 \\
\hline & 2.2 .4 & 140 & 20.64 & 100,264 & 34.65 & 0.60 \\
\hline & 2.2 .2 & 4 & 0.58 & 16,458 & 5.68 & 0.10 \\
\hline & 2.2 .3 & 461 & 67.99 & 151,179 & 52.25 & 1.30 \\
\hline \multirow{9}{*}{ Geology } & L-ml2 & 8 & 1.17 & 20,023 & 6.86 & 0.17 \\
\hline & L-ml3 & 7 & 1.02 & 25,934 & 8.89 & 0.11 \\
\hline & L-PLL2 & 347 & 50.66 & 104,339 & 35.77 & 1.42 \\
\hline & L-PLL3 & 203 & 29.64 & 100,577 & 34.48 & 0.86 \\
\hline & L-PLL4 & 0 & 0 & 3452 & 1.18 & 0 \\
\hline & L-PLL1 & 42 & 6.13 & 19,968 & 6.84 & 0.90 \\
\hline & L-R & 17 & 2.48 & 5441 & 1.87 & 1.33 \\
\hline & L-K212 & 2 & 0.29 & 4358 & 1.49 & 0.20 \\
\hline & L-Pel1 & 59 & 8.61 & 7629 & 2.62 & 3.29 \\
\hline
\end{tabular}

The ratio weights between the slope aspect and landslides showed that landslides are more likely to occur on northeast, north, and east-facing slopes, respectively (Table 1). Slope aspect is related to meteorological events such as rainfall, exposure to sunlight, dry winds, and morphological structures that promote landslide occurrence.

Table 1 shows the ratio weight of geological and the landslides in the class L-PLL2 code representing relatively high altitudes with a moderate slope, medium soil depth, low stability and permeability, and dominant sediments, sandy lime, limestone, and conglomerates have the highest number of landslides.

The databases include the landslide triggering factors that were constructed in the raster format using identical spatial projection and cell size $(20 \times 20 \mathrm{~m})$. Finally, from the 
combination of the raster layers of the effective factors and landslide inventory map, we produced a landslide risk zonation map using the frequency ratio procedure (Figure 4) [58].

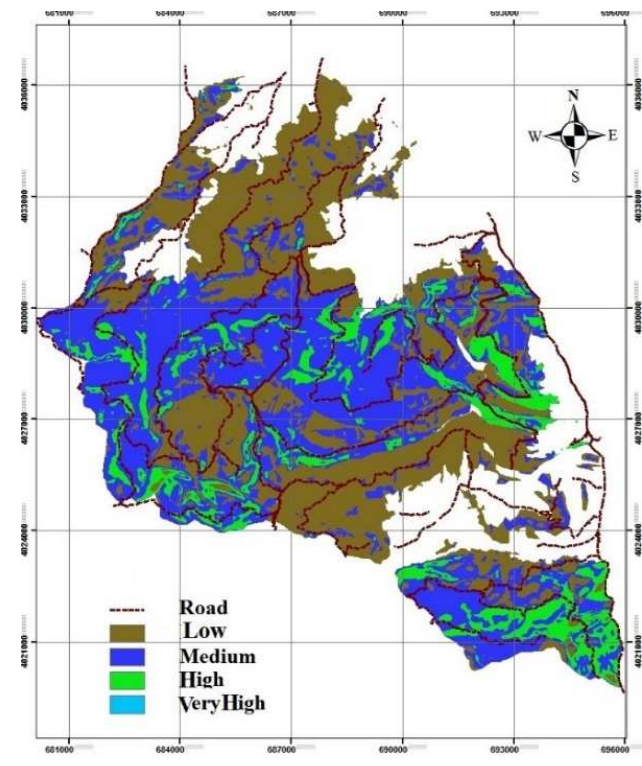

(a)

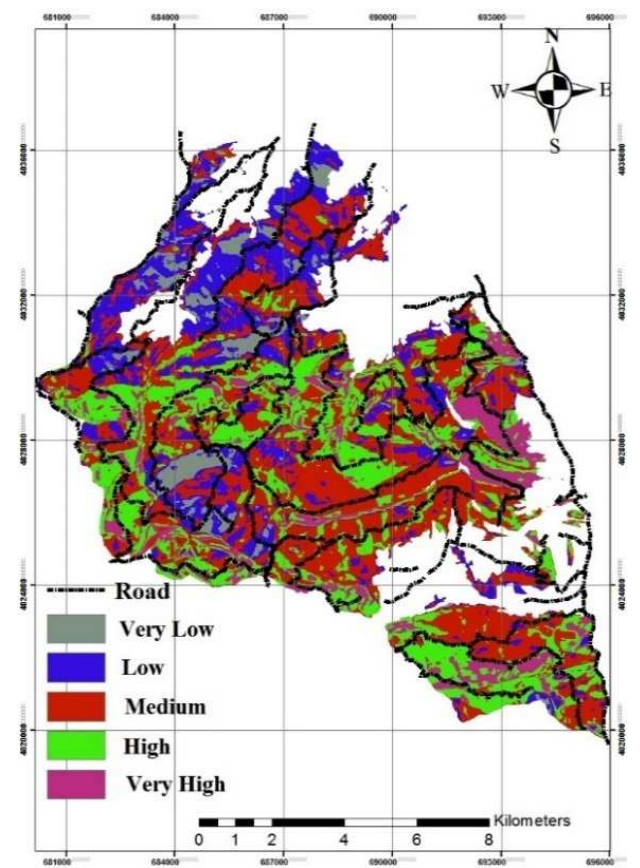

(c)

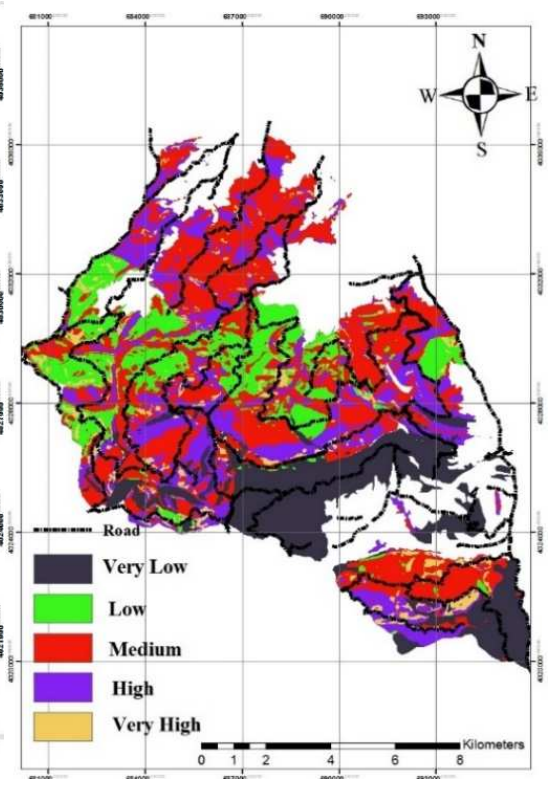

(b)

Figure 4. Landslide susceptibility maps created using ANFIS and frequency ratio models: (a) Frequency ratio; (b) triangular MF; (c) Gaussian MF.

Next we performed the model evaluation in SPSS (version 14.1) using the ROC CURVE program, where the area under curve (AUC) shows the accuracy. The validation rate is $68.8 \%$ for the frequency ratio method (Figure 5). The ROC curve was made based on the sensitivity (in our case, the percentage of unstable pixels correctly predicted by the model) and 1-specificity (the percentage of predicted unstable pixels over the total) with the different cut-off thresholds [78]. 


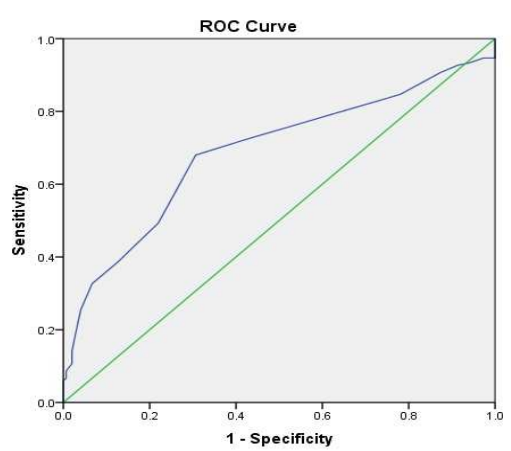

(a)

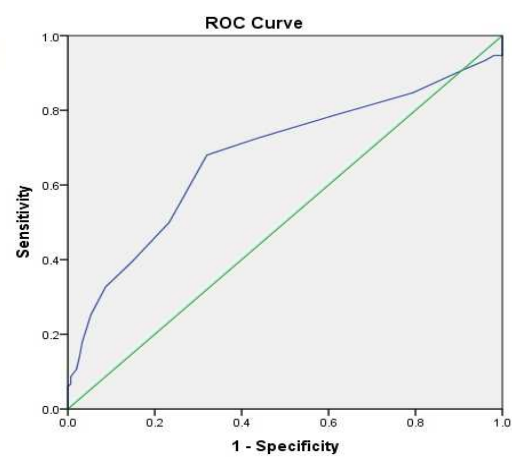

(b)

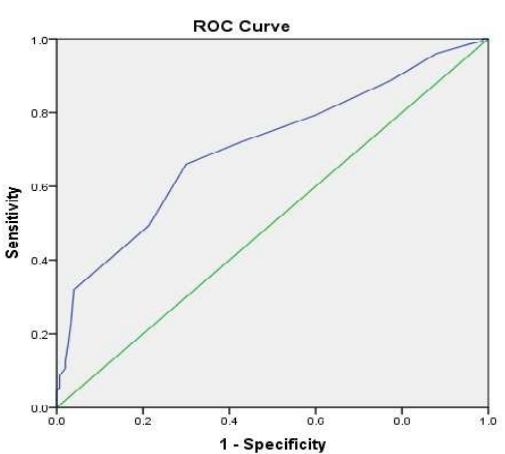

(c)

Figure 5. Receiver operating characteristics (ROC) curve showing the area under curve for the landslide susceptibility maps produced using various MFs in ANFIS based models and Frequency ratio model: (a) AUC $=68.8 \%$; (b) AUC $=67.8 \%$; (c) $\mathrm{AUC}=70.7 \%$.

\subsection{The Application of ANFIS}

Adaptive neuro-fuzzy modeling (ANFIS) makes anticipations based on learning the "if-then" rules between triggering factors and landslide incidence. ANFIS maintains the benefits of fuzzy logic and ANNs models simultaneously, making it a robust model for Landslide Susceptibility assessment. Similar to all LS models, the relative accuracy of ANFIS depends on the selected parameters, such as cell size, types and the number of relevant factors, normalization of relevant factor data, classification of output LS maps, sizes of datasets used for training, checking and validation [26]. In the current analysis with a cell size of $20 \mathrm{~m}$, eight effective factors normalized by their FR values were used to generate the desired LS maps. To prepare a map, the 1967 cells were matched with their relative normalized values of each factor to make a database. Subsequently, an ANFIS model for the LS assessment was developed and trained using the above datasets within the MATLAB (9.5) software package. The first layer of the model was fed with the eight conditioning factors as inputs. The last layer of the model contained a single node that represented the presence or absence of landslides (an output of 1 for presence, and 0 for absence). To start the training process, the type and the number of MFs were decided. In this study, two types of MFs, namely Gaussian and triangular, were assessed. By entering this data into the optimal ANFIS model for each membership function separately, the output value of each pixel was calculated. The value calculated by the model was transferred to the attribute table of the area map and the final map of landslide sensitivity was obtained (Figure 4) [26,60].

Landslide susceptibility classes (very high risk, high risk, moderate risk, low risk and very low risk), should be defined by expert judgment accompanied by appropriate model results [63]. Landslide susceptibility classes indicate the result of occurrence likelihood along with its consequence for the elements at risk. The assessment results were confirmed for the observed landslide locations. The landslide locations were divided, with $70 \%$ used as the training dataset and $30 \%$ used as the validation dataset. In order to validate the results, the AUC of the ROC curve was calculated for both maps $[24,38,58,63,78]$. The rate describes how well the model and the factors forecast subsidence, and the AUC quantifies the forecast accuracy [27]. A good fit model has an AUC value from 0.5 to 1 . The ideal model has an AUC value close to 1.0 (perfect fit) [68].

\section{Conclusions}

The spatial prediction of landslides remains a challenging task in landslide hazard and risk assessment. The accuracy of a landslide prediction model depends, in part, on the method applied in the model. Therefore, the investigation of new methods is required to improve predictive power continuously. This study applied the integration of the frequency ratio and ANFIS models to LS mapping along with resource road networks in an Iranian 
mountain forest. One hundred and fifty landslides that occurred during recent years were identified and mapped from field surveys. The end product of GIS-based ANFIS application and the frequency ratio method was a set of three susceptibility maps, which could be used to predict the stability of slopes from eight fundamental factors.

The frequency ratio model indicated incremental landslide susceptibility on slope class $50-60 \%$, north and northeast facing slope, altitude $600-900 \mathrm{~m}$, rainfall greater than $750 \mathrm{~mm}$, in fill slope, roads less than 20 years old, soil with loam, clay loam, and clay texture. Like in the studies of Arabameri et al. [48-50] for different forests in Manzadran Province, we too found that roads were the main factor contributing to landslides.

The result of the frequency ratio was compared with the result of two ANFIS models and our results showed that each susceptibility map performed reasonably well with AUC between $67.8 \%$ to $70.7 \%$. The validation results of the map obtained by Gaussian and the triangular membership functions in the ANFIS method showed that the difference in validation accuracy is $2.9 \%$, indicating that the choice of MFs was not important in this study. Lee et al. [27] conducted a similar study in Korea and the results were similar. There were differences in some details, such as the factors affecting the occurrence of landslides and dividing the data into two parts: training and testing. They also reported that, because of the proximity of the AUC value in the two membership functions, there was no difference in the membership's selection for modeling the ANFIS.

This study has prepared a landslide susceptibility map after the construction of the forest road network in order to reduce maintenance costs by focusing more on protection operations in classes prone to landslides. Analyzing road route selection is a time-consuming task that requires the evaluation of various criteria, including multiple routes. Estimations of landslide sensitivity is considered to be an element that has a great impact on costs as a prerequisite before designing a road network. Qhajar and Najafi [61] modeled the susceptibility to landslides using ANFIS in the forests of northern Iran before designing the road. Their results showed that a large part of the region is in the category of medium and high sensitivity to landslides. The design and construction of roads that have been built so far in the region have followed almost the same proportions of the whole region and most of their area is classified as medium and high sensitivity classes.

It is important to choose routes that avoid potentially unstable areas to promote road life, reduce maintenance costs, and avoid environmental degradation

Finally, because the resulting LS maps are simple and easy to follow, ANFIS modeling is a good selection for shallow landslide hazard zonation. The approach used in this investigation can be extended to consider landslides in other areas. To make more use of this method, more landslides data are needed, and more case studies need to be done. It is also important to note that the efficiency of the ANFIS-derived susceptibility maps depends not only on the methodology but also on the quality of the available data. Our LS maps can guide the planning and management of forest road networks, promoting safe forestry operations. Regrettably, such studies are far from common in the mountainous forestlands of Iran, and we encourage similar studies to be conducted in other working forests.

Author Contributions: Conceptualization, S.A.O.H., N.Z. and M.K.H.; methodology, S.A.O.H., N.Z., A.N. and B.M.; software and validation, N.Z. and A.N.; writing—original draft preparation, N.Z.; writing - review and editing, N.Z., A.N. and M.G. All authors have read and agreed to the published version of the manuscript.

Funding: This research was funded by Iran National Science Foundation, grant number 96002191.

Acknowledgments: This study was supported by the Mazandaran Wood \& Paper Industries and University of Tehran. We thank James Jacklin and two anonymous reviewers for helpful comments on our paper.

Conflicts of Interest: The authors declare no conflict of interest. The funders had no role in the design of the study; in the collection, analyses, or interpretation of data; in the writing of the manuscript, or in the decision to publish the results. 


\section{References}

1. Gumus, S.; Acar, H.H.; Toksoy, D. Functional forest road network planning by consideration of environmental impact assessment for wood harvesting. Environ. Monit. Assess. 2008, 142, 109-116. [CrossRef] [PubMed]

2. Abdi, E.; Majnounian, B.; Darvishsefat, A.; Mashayekhi, Z.; Sessions, J. A GIS-MCE based model for forest road planning. J. For. Sci. 2009, 55, 171-176. [CrossRef]

3. Deljouei, A.; Abdi, E.; Marcantonio, M.; Majnounian, B.; Amici, V.; Sohrabi, H. The impact of forest roads on understory plant diversity in temperate hornbeam-beech forests of Northern Iran. Environ. Monit. Assess. 2017, 189, 392. [CrossRef] [PubMed]

4. Deljouei, A.; Sadeghi, S.M.M.; Abdi, E.; Bernhardt-Römermann, M.; Pascoe, E.L.; Marcantonio, M. The impact of road disturbance on vegetation and soil properties in a beech stand, Hyrcanian forest. Eur. J. For. Res. 2018, 137, 759-770. [CrossRef]

5. Swanson, F.J.; Dyrness, C.T. Impact of clear-cutting and road construction on soil erosion by landslides in the western Cascade Range, Oregon. Geology 1975, 3, 393-396. [CrossRef]

6. Montgomery, D.R. Road surface drainage, channel initiation, and slope instability. Water Resour. Res. 1994, 30, 1925-1932. [CrossRef]

7. Borga, M.; Tonelli, F.; dalla Fontana, G.; Cazorzi, F. Evaluating the influence of forest roads on shallow landsliding. Ecol. Model. 2005, 187, 85-98. [CrossRef]

8. Gorsevski, P.V.; Gessler, P.E.; Foltz, R.B.; Elliot, W.J. Spatial prediction of landslide hazard using logistic regression and ROC analysis. Trans. GIS 2006, 10, 395-415. [CrossRef]

9. Imaizumi, F.; Sidle, R.C.; Kamei, R. Effects of forest harvesting on the occurrence of landslides and debris flows in steep terrain of central Japan. Earth Surf. Process. Landf. 2008, 33, 827-840. [CrossRef]

10. Geertsema, M.; Schwab, J.; Jordan, P.; Millard, T.; Rollerson, T. Chapter 8-Hillslope processes. In Compendium of Forest Hydrology and Geomorphology in British Columbia; British Columbia: Victoria, BC, Canada, 2010; Volume 66, pp. 213-273. Available online: https://www.for.gov.bc.ca/hfd/pubs/Docs/Lmh/Lmh66/Lmh66_ch08.pdf (accessed on 1 March 2010).

11. Jordan, P.; Millard, T.; Campbell, T.; Schwab, J.; Wilford, D.; Nicol, D.; Collins, D. Chapter 9—Forest Management effects on hillslope processes. In Compendium of Forest Hydrology and Geomorphology in British Columbia; British Columbia: Victoria, BC, Canada, 2010; Volume 66, pp. 275-329. Available online: https://www.for.gov.bc.ca/hfd/pubs/Docs/Lmh/Lmh66/Lmh66_ch0 9.pdf (accessed on 1 March 2010).

12. Jaafari, A.; Rezaeian, J.; Shafipour Omrani, M. Spatial prediction of slope failures in support of forestry operations safety. Croat. J. For. Eng. 2017, 38, 107-118.

13. Deljouei, A.; Abdi, E. Seasonal and spatial variability of root reinforcement in three pioneer species of the Hyrcanian forest. Austrian J. For. Sci. 2019, 136, 175-198.

14. Schwab, J.W.; Geertsema, M. Terrain stability mapping on British Columbia forest lands: An historical perspective. Nat. Hazards 2010, 53, 63-75. [CrossRef]

15. Schuster, R.L.; Highland, L.M. The Third Hans Cloos Lecture. Urban landslides: Socioeconomic impacts and overview of mitigative strategies. Bull. Eng. Geol. Environ. 2007, 66, 1-27. [CrossRef]

16. Geertsema, M.; Highland, L.; Vaugeouis, L. Environmental impact of landslides. In Landslides—Disaster Risk Reduction; Springer: Berlin/Heidelberg, Germany, 2009; pp. 589-607.

17. Kjekstad, O.; Highland, L. Economic and social impacts of landslides. In Landslides_Disaster Risk Reduction; Springer: Berlin/Heidelberg, Germany, 2009; pp. 573-587.

18. Geertsema, M.; Pojar, J.J. Influence of landslides on biophysical diversity-A perspective from British Columbia. Geomorphology 2017, 89, 55-69. [CrossRef]

19. Walker, L.R.; Shiels, A.B. Landslide Ecology; Cambridge University Press: New York, NY, USA, 2012; 300p.

20. Moosavi, V.; Niazi, Y. Development of hybrid wavelet packet-statistical models (WP-SM) for landslide susceptibility mapping. Landslides 2016, 13, 97-114. [CrossRef]

21. Pradhan, B.; Lee, S. Delineation of landslide hazard areas on Penang Island, Malaysia, by using frequency ratio, logistic regression, and artificial neural network models. Environ. Earth Sci. 2010, 60, 1037-1054. [CrossRef]

22. Pradhan, B.; Lee, S. Landslide susceptibility assessment and factor effect analysis: Back-propagation artificial neural networks and their comparison with frequency ratio and bivariate logistic regression modelling. Environ. Ment. Model. Softw. 2010, 25, 747-759. [CrossRef]

23. Brabb, E.E. Innovative approaches to landslide hazard mapping. In Proceedings of the IV International Symposium of Landslides, Canadian Geotechnical Society, Toronto, ON, Canada, 16-21 September 1984.

24. Bui, D.T.; Pradhan, B.; Lofman, O.; Revhaug, I.; Dick, O.B. Landslide susceptibility mapping at Hoa Binh province (Vietnam) using an adaptive neuro fuzzy inference system and GIS. Comput. Geosci. 2012, 45, 199-211.

25. Van Westen, C.J.; Castellanos, E.; Kuriakose, S.L. Spatial data for landslide susceptibility, hazard, and vulnerability assessment: An overview. Eng. Geol. 2008, 102, 112-131. [CrossRef]

26. Polykretis, C.; Chalkias, C.; Ferentinou, M. Adaptive neuro-fuzzy inference system (ANFIS) modeling for landslide susceptibility assessment in a Mediterranean hilly area. Bull. Eng. Geol. Environ. 2019, 78, 1173-1187. [CrossRef]

27. Lee, M.J.; Park, I.; Lee, S. Forecasting and validation of landslide susceptibility using an integration of frequency ratio and neuro-fuzzy models: A case study of Seorak mountain area in Korea. Environ. Earth Sci. 2015, 74, 413-429. [CrossRef] 
28. Lepore, C.; Kamal, S.A.; Shanahan, P.; Bras, R.L. Rainfall-induced landslide susceptibility zonation of Puerto Rico. Environ. Earth Sci. 2012, 66, 1667-1681. [CrossRef]

29. Oh, H.J.; Park, N.W.; Lee, S.S.; Lee, S. Extraction of landslide related factors from ASTER imagery and its application to landslide susceptibility mapping. Int. J. Remote Sens. 2012, 33, 3211-3231. [CrossRef]

30. Neuhauser, B.; Damm, B.; Terhorst, B. GIS-based assessment of landslide susceptibility on the base of the Weights-of-Evidence model. Landslides 2012, 9, 511-528. [CrossRef]

31. Schicker, R.; Moon, V. Comparison of bivariate and multivariate statistical approaches in landslide susceptibility mapping at a regional scale. Geomorphology 2012, 161-162, 40-57. [CrossRef]

32. Lee, S.; Hwang, J.; Park, I. Application of data-driven evidential belief functions to landslide susceptibility mapping in Jinbu, Korea. Catena 2013, 100, 15-30. [CrossRef]

33. Feizizadeh, B.; Blaschke, T.; Nazmfar, H. GIS-based ordered weighted averaging and Dempster-Shafer methods for landslide susceptibility mapping in the Urmia Lake Basin, Iran. Int. J. Digit. Earth 2014, 7, 688-708. [CrossRef]

34. Devkota, K.C.; Regmi, A.D.; Pourghasemi, H.R.; Yoshida, K.; Pradhan, B.; Ryu, I.C.; Dhital, M.R.; Althuwaynee, O.F. Landslide susceptibility mapping using certainty factor, index of entropy and logistic regression models in GIS and their comparison at Mugling-Narayanghat road section in Nepal Himalaya. Nat. Hazard. 2013, 65, 135-165. [CrossRef]

35. Li, Y.; Chen, G.; Tang, C.; Zhou, G.; Zheng, L. Rainfall and Earthquake-induced landslide susceptibility assessment using GIS and Artificial Neural Network. Nat. Hazard. Earth Syst. Sci. 2012, 12, 2719-2729. [CrossRef]

36. Ramakrishnan, D.; Singh, T.N.; Verma, A.K.; Gulati, A.; Tiwari, K.C. Soft computing and GIS for landslide susceptibility assessment in Tawaghat area, Kumaon Himalaya, India. Nat. Hazards 2013, 65, 315-330. [CrossRef]

37. Bui, D.T.; Pradhan, B.; Lofman, O.; Revhaug, I.; Dick, O.B. Regional prediction of landslide hazard using probability analysis of intense rainfall in the Hoa Binh province, Vietnam. Nat. Hazards. 2013, 66, 707-730.

38. Yilmaz, I. Comparison of landslide susceptibility mapping methodologies for Koyulhisar, Turkey: Conditional probability, logistic regression, artificial neural networks, and support vector machine. Environ. Earth Sci. 2010, 61, 821-836. [CrossRef]

39. Pradhan, B. A comparative study on the predictive ability of the decision tree, support vector machine and neuro-fuzzy models in landslide susceptibility mapping using GIS. Comput. Geosci. 2013, 51, 350-365. [CrossRef]

40. Wan, S.; Lei, T.C.; Chou, T.Y. A novel data mining technique of analysis and classification for landslide problems. Nat. Hazards 2010, 52, 211-230. [CrossRef]

41. Lee, S.; Choi, J.; Oh, H. Landslide susceptibility mapping using a neuro-fuzzy. In Proceedings of the Abstract Presented at the American Geophysical Union, Fall Meeting, San Francisco, CA, USA, 13-17 December 2009.

42. Pradhan, B.; Sezer, E.A.; Gokceoglu, C.; Buchroithner, M.F. Landslide susceptibility mapping by neuro-fuzzy approach in a landslide-prone area (Cameron Highlands, Malaysia). IEEE Trans. Geosci. Remote Sens. 2010, 48, 4164-4177. [CrossRef]

43. Vahidnia, M.H.; Alesheikh, A.A.; Alimohammadi, A.; Hosseinali, F. A GIS-based neuro-fuzzy procedure for integrating knowledge and data in landslide susceptibility mapping. Comput. Geosci. 2010, 36, 1101-1114. [CrossRef]

44. Oh, H.J.; Pradhan, B. Application of a neuro-fuzzy model to landslide-susceptibility mapping for shallow landslides in a tropical hilly area. Comput. Geosci. 2011, 37, 1264-1276. [CrossRef]

45. Hosseini, S.A. Cognition, Usage and Management of Forest Machinery; Ghalam Emamat Press: Tehran, Iran, 2017; 189p.

46. Rasai, A.; Khosravi, K.; Habibnejad Roshan, M.; Heidari, A.; Mashayekh Khan, A. Lnadslide Hazard Zonation using Multivariate Regression in GIS Environment (Case Study: Aghmashhad Watershed, Mazandaran). J. Watershed Manag. Res. 2015, 6, 205-215.

47. Moradi, H.R. Landslide hazard Susceptibility Mapping and its Evaluation Using the Statistics Analysis logistic Regression. J. Range Watershed Manag. 2015, 67, 617-629.

48. Arabameri, A.; Pradhan, B.; Rezaei, K.; Lee, C.W. Assessment of landslide susceptibility using statistical-and artificial intelligencebased FR-RF integrated model and multiresolution DEMs. Remote Sens. 2019, 11, 999. [CrossRef]

49. Arabameri, A.; Pradhan, B.; Rezaei, K.L.; Sohrabi, M. An ensemble model for landslide susceptibility mapping in a forested area. Geocarto Int. 2020, 35, 1680-1705. [CrossRef]

50. Arabameri, A.; Karimi-Sangchini, E.; Pal, S.C.; Saha, A.; Chowdhuri, I.; Lee, S.; Tien Bui, D. Novel Credal Decision Tree-Based Ensemble Approaches for Predicting the Landslide Susceptibility. Remote Sens. 2020, 12, 3389. [CrossRef]

51. Memarian, H. Engineering Geology and Geotechnics, 6th ed.; University of Tehran Press: Tehran, Iran, 2013; 992p.

52. Cruden, D.M. Estimating the risks from landslides using historical data. In Landslide Risk Assessment; Cruden, D.M., Fell, R., Eds.; Balkema Pub.: Rotterdam, The Netherlands, 1997; pp. 177-184.

53. Lee, S.; Thalib, J.A. Probabilistic landslide susceptibility and factor effect analysis. Environ. Geol. 2005, 47, 982-990. [CrossRef]

54. Brardinoni, F.; Slaymaker, O.; Hassan, M.A. Landslide inventory in a rugged forested watershed: A comparison between air-photo and field survey data. Geomorphology 2003, 54, 179-196. [CrossRef]

55. Guzzetti, F.; Carrara, A.; Cardinali, M.; Reichenbach, P. Landslide hazard evaluation: A review of current techniques and their application in a multi-scale study, Central Italy. Geomorphology 1999, 31, 181-216. [CrossRef]

56. Ayalew, L.; Yamagishi, H. The application of GIS-based logistic regression for landslide susceptibility mapping in the KakudaYahiko Mountains, Central Japan. Geomorphology 2005, 65, 15-31. [CrossRef]

57. Rasyid, A.R.; Bhand, N.P.; Yatabe, R. Performance of frequency ratio and logistic regression model in creating GIS based landslides susceptibility map at Lompobattang Mountain, Indonesia. Geoenviron. Disasters 2016, 3, 19. [CrossRef] 
58. Jaafari, A.; Najafi, A.; Pourghasemi, H.R.; Rezaeian, J.; Sattarian, A. GIS-based frequency ratio and index of entropy models for landslide susceptibility assessment in the Caspian forest, northern Iran. Int. J. Environ. Sci. Technol. 2014, 11, 909-926. [CrossRef]

59. Ghajar, I.; Najafi, A.; Torabi, S.A.; Khamehchiyan, M.; Boston, K. An Adaptive Network based Fuzzy Inference System for Rock Share Estimation in Forest Road Construction. Croat. J. For. Eng. 2012, 33, 313-328.

60. Hosseini, S.A.; Savadkuhi, N.M. Assessment and Studying Landslide, its type and displacement along Forest Road Edge (Case study: Tajan Watershed-Mazandaran). Res. J. For. Sci. Eng. 2011, 1, 1-11.

61. Ghajar, I.; Najafi, A. Modeling landslide susceptibility of a mountain forests using Adaptive Neuro-Fuzzy Inference System (ANFIS) for forest road planning. Iran. J. For. Pop. Res. 2014, 22, 509-526.

62. Jaafari, A.; Najafi, A.; Rezaeian, J.; Sattarian, A.; Ghajar, E. Planning road networks in Landslide-prone areas: A case study from the northern forest of Iran. Land Use Policy 2015, 47, 198-208. [CrossRef]

63. Pourghasemi, H.R.; Mohammady, M.; Pradhan, B. Landslide susceptibility mapping using index of entropy and conditional probability models in GIS: Safarood Basin, Iran. Catena 2012, 97, 71-84. [CrossRef]

64. Budimir, M.E.; Atkinson, P.M.; Lewis, H.G. A systematic review of landslide probability mapping using logistic regression. Landslides 2015, 12, 419-436. [CrossRef]

65. Dewitte, O.; Chung, C.J.; Cornet, Y.; Daoudi, M.; Demoulin, A. Combining spatial data in landslide reactivation susceptibility mapping: A likelihood ratio-based approach in W Belgium. Geomorphology 2010, 122, 153-166. [CrossRef]

66. Ozdemir, A. Landslide susceptibility mapping of vicinity of Yaka landslide (Gelendost, Turkey) using conditional probability approach in GIS. Environ. Geol. 2009, 57, 1675-1686. [CrossRef]

67. Yilmaz, I. Landslide susceptibility mapping using frequency ratio, logistic regression, artificial neural networks and their comparison: A case study from Kat landslides (Tokat-Turkey). Comput. Geosci. 2009, 35, 1125-1138. [CrossRef]

68. Aditian, A.; Kubota, T.; Shinohara, Y. Comparison of GIS-based landslide susceptibility models using frequency ratio, logistic regression, and artificial neural network in a tertiary region of Ambon, Indonesia. Geomorphology 2018, 318, 101-111. [CrossRef]

69. Yalcin, A.; Reis, S.; Aydinoglu, A.C.; Yomralioglu, T. A GIS-based comparative study of frequency ratio, analytical hierarchy process, bivariate statistics and logistics regression methods for landslide susceptibility mapping in Trabzon, NE Turkey. Catena 2011, 85, 274-287. [CrossRef]

70. Chen, W.; Zhang, S. GIS-based comparative study of Bayes network, Hoeffding tree and logistic model tree for landslide susceptibility modeling. Catena 2021, 203, 15344. [CrossRef]

71. Regmi, A.D.; Devkota, K.C.; Yoshida, K.; Pradhan, B.; Pourghasemi, H.R.; Kumamoto, T.; Akgun, A. Application of frequency ratio, statistical index, and weights-of-evidence models and their comparison in landslide susceptibility mapping in Central Nepal Himalaya. Arab. J. Geosci. 2014, 7, 725-742. [CrossRef]

72. Mohammady, M.; Pourghasemi, H.R.; Pradhan, B. Landslide susceptibility mapping at Golestan Province Iran: A comparison between frequency ratio, Dempster-Shafer, and weights-of evidence models. J. Asian Earth Sci. 2012, 61, 221-236. [CrossRef]

73. Ozdemir, A.; Altural, T. A comparative study of frequency ratio, weights of evidence and logistic regression methods for landslide susceptibility mapping: Sultan Mountains, SW Turkey. J. Asian Earth Sci. 2013, 64, 180-197. [CrossRef]

74. Jang, J.S. ANFIS: Adaptive-network-based fuzzy inference system. IEEE Trans. Syst. Man Cybern. 1993, 23, 665-685. [CrossRef]

75. Akib, S.; Mohammadhassani, M.; Jahangirzadeh, A. Application of ANFIS and LR in prediction of scour depth in bridges. Comput. Fluids 2014, 91, 77-86. [CrossRef]

76. Takagi, T.; Sugeno, M. Derivation of fuzzy control rules from human operator's control actions. In Proceedings of the IFAC Symposium on Fuzzy Information, Knowledge Representation and Decision Analysis, Marseille, France, 19-21 July 1983; pp. 55-60.

77. Dixon, B. Applicability of neuro-fuzzy techniques in predicting groundwater vulnerability: A GIS-based sensitivity analysis. J. Hydrol. 2005, 309, 17-38. [CrossRef]

78. Chen, W.; Chen, X.; Peng, J.; Panahi, M.; Lee, S. Landslide susceptibility modeling based on ANFIS with teaching-learning-based optimization and Satin bowerbird optimizer. Geosci. Front. 2021, 12, 93-107. [CrossRef]

79. Dehnavi, A.; Nasiri Aghdam, I.; Pradhan, B.; Morshed Varzandeh, M.H. A new hybrid model using step-wise weight assessment ratio analysis (SWARA) technique and adaptive neuro-fuzzy inference system (ANFIS) for regional landslide hazard assessment in Iran. Catena 2015, 135, 122-148. [CrossRef]

80. Hong, H.; Pradhan, B.; Xu, C.; Bui, D.T. Spatial prediction of landslide hazard at the Yihuang area (China) using two-class kernel logistic regression, alternating decision tree and support vector machines. Catena 2015, 133, 266-281. [CrossRef]

81. Farahnak, M.; Mitsuyasu, K.; Jeong, S.; Otsuki, K.; Chiwa, M.; Sadeghi, S.M.M.; Kume, A. Soil hydraulic conductivity differences between upslope and downslope of two coniferous trees on a hillslope. J. For. Res. 2019, 24, 143-152. [CrossRef]

82. Van Westen, C.J.; Asch, T.W.J.; Soeters, R. Landslide hazard and risk zonation-Why is it still so difficult. Bull. Eng. Geol. Environ. 2006, 65, 67-184. [CrossRef] 